\title{
悪性貧血を背景として脳梗塞を発症し， 機械的血栓回収療法により良好な転㷌を得た 1 例
}

\author{
村瀬 翔 ${ }^{1)^{*}}$ 牧 貴紀 2 ,3)* 福村 匡央 ${ }^{2)}$ \\ 黒田 雄三 ${ }^{2)}$ 権 泰史 ${ }^{1)}$ 中澤 和智2
}

\begin{abstract}
要旨：症例は 83 歳男性．意識障害にて救急搬送となった，来院時 NIHSS は 17 点で, 頭部 MRA で左 MCA 閉塞 (M1 遠位部)を認めた．頭部 CT, MRI で早期虚血変化を認めず，血管内再開通療法 の適応があると判断した．血液検查で $\mathrm{Hb} 3.8 \mathrm{~g} / \mathrm{dl}, \mathrm{MCV} 144 \mathrm{fl}$ と高度大球性貧血を認め, 活動性消化 管出血が否定できないことから，rt-PA 静注療法は施行しなかった，輸血療法および機械的血栓回収 療法を迅速に施行し, 左中大脳動脈の完全再開通を得た。上部消化管内視鏡検查にて慢性萎縮性胃 炎を認め, 血清 vitamin $\mathrm{B}_{12}$ 值の低下を認めたことから, 悪性貧血による高度大球性貧血と診断し た. 入院後, 抗凝固療法抢よび vitamin $\mathrm{B}_{12}$ 補充療法を導入の上, 第 13 病日に後遺症なく退院した. 脳梗塞急性期において, 血管内再開通療法の適応を判断する際にも, 貧血を含めた基礎疾患の確認 と全身管理を並行して行うことが重要である.
\end{abstract}

Key words: pernicious anemia, severe anemia, mechanical thrombectomy, vitamin $\mathrm{B}_{12}$ deficiency

\section{緒 言}

貧血は，脳卒中患者における転帰不良因子として知ら れており， $\mathrm{Hb}$ 低下に伴い末梢組織への酸素供給が低下 することで，脳血管における自動調節能の障害，末梢血 管内皮障害の惹起，心不全および腎機能増悪の助長な ど，さまざまな機序で脳卒中発症後の脳実質障害を進展 させると考えられている ${ }^{1,2)}$ 。また，脳梗塞発症時に高 度貧血を有する症例では, rt-PA 静注療法を含めた血管 内再開通療法の適応判断に難渋することもしばしばであ り，機械的血栓回収療法における転帰も不良であったと 報告されている ${ }^{3)}$. 今回，我々は，悪性貧血の進行に伴 う高度大球性貧血により脳梗塞を発症し, 機械的血栓回 収療法により良好な転帰を得た症例を経験したので報告 する。

\footnotetext{
1)社会医療法人協和会加納総合病院脳神経内科

2)社会医療法人協和会加納総合病院脳神経外科

${ }^{3)}$ 医療法人良善会ひかり病院

*equally contributed

責任著者： $\overline{7} 531-0041$ 大阪府大阪市北区天神橋 7 丁目 5-15 社会医療法人協和会加納総合病院脳神経内科 村瀬 翔

E-mail: murase-fki@umin.ac.jp

( 2020 年 11 月 1 日受付, 2020 年 12 月 6 日受理)

doi: $10.3995 /$ jstroke. 10870
}

\section{症例呈示}

患者：83 歳, 男性

主訴：意識障害

既往歴：特記すべきことなし

家族歴：特記すべきことなし

現病歴：入院 5 力月程度前から倦急感を自覚していた が，起立時のふらつきの自覚はなく，吐下血や黒色便も なかったため, 医療機関は受診せず経過観察していた。 入院当日，16 時までは普段通りであったが，18 時に反 応が鈍いことに家人が気付き，当院へ救急搬送された。

入院時現症：身長 $162 \mathrm{~cm}$, 体重 $40.5 \mathrm{~kg}$. 血圧 142/62 mmHg, 心拍数 92 回/分. 整. 呼吸数 16 回/分, $\mathrm{SpO}_{2} 98 \%$ (室内気). 両側眼瞼結膜は蒼白であったが, 舌や爪を含め, その他理学所見に異常を認めなかった。 神経学的所見としては, 失語, 右半側空間無視, 右不全 片麻痺を認め, NIHSS は 17 点であった。

検查所見：頭部単純 CT では明らかな出血性病変を認 めず, Alberta Stroke Program Early CT(ASPECT)Score は 10 点であった。頭部単純 MRI では，DWI で明らかな急 性期虚血性変化は認めず (DWI-ASPECT Score 11 点; Fig. 1A，B），頭部 MRA にて左中大脳動脈遠位部に閉塞 を認めた (Fig. 1C)。血液検査では，血算で高度大球性貧 


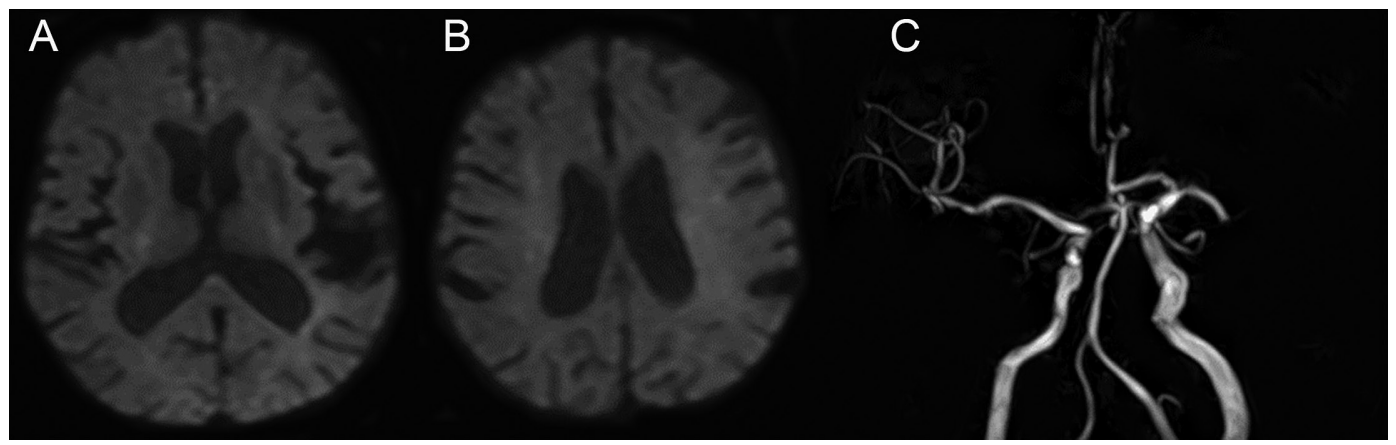

Fig. 1 入院時の画像所見 DWI では明らかな信号変化を認めなかった $(\mathrm{A}, \mathrm{B})$. MRA では左中大脳動脈閉塞を認めた $(\mathrm{C})$.

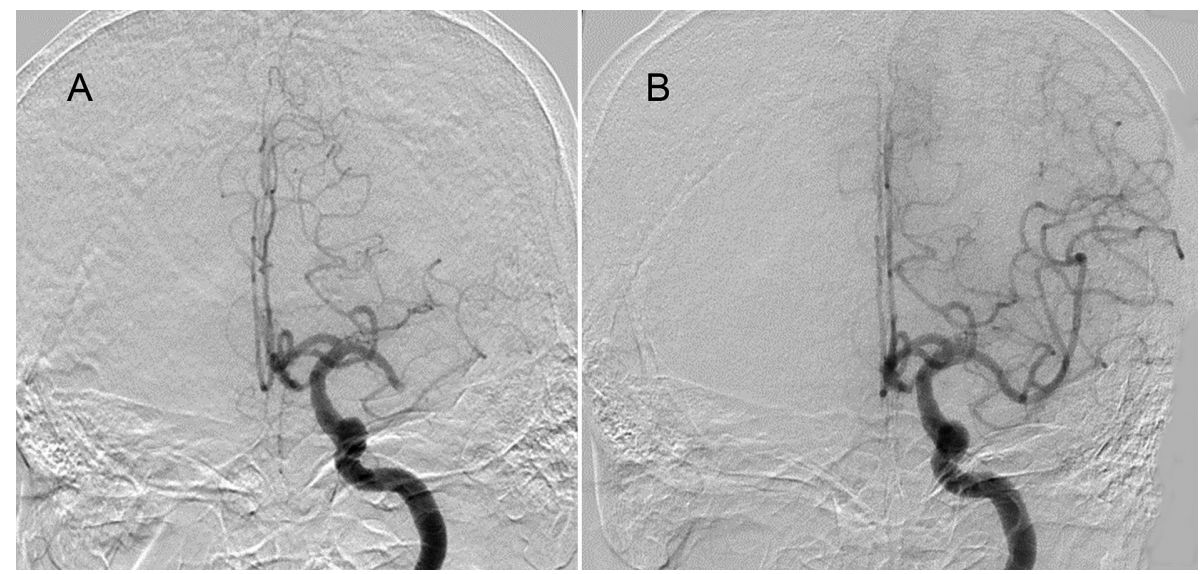

Fig. 2 機械的血栓回収療法施行時の画像所見 治療前 $(\mathrm{A})$. 治療後, 左中大脳動脈の完全再開通を認めた (B).

血. (hemoglobin: $\mathrm{Hb} 3.8 \mathrm{~g} / \mathrm{dl}$, mean corpuscular volume: MCV $144 \mathrm{fl})$ を認めたほか, 白血球 $(2650 / \mu \mathrm{l})$ および血小板数 $\left(10.4 \times 10^{4} / \mu 1\right)$ の軽度低下を認めた。肝機能, 腎機能に異 常はなく，凝固線溶系においてPT-INR $(0.97)$ おび $\operatorname{APTT}(25.8$ 秒) は正常範囲内であった.

経過：神経学的所見および画像検査所見から，急性期 脳梗塞および左中大脳動脈急性閉塞と診断した. 最終未 発症確認時刻より 4.5 時間以内であったが, 活動性消化 管出血の可能性を否定できないことから, rt-PA 静注療 法は施行しない方針とした. 赤血球濃厚液 4 単位を投与 するとともに，機械的血栓回収療法(Trevo XP ProVue Retriever; Stryker, Kalamazoo, MI, USA, Penumbra ACE 68; Penumbra, Alameda, CA, USA)を施行したところ, 1pass にて左中大脳動脈の完全再開通が得られ(Thrombolysis in Cerebral Infarction: TICI 3, 穿刺〜再開通 20 分) (Fig. $2 \mathrm{~A}, \mathrm{~B})$, 術直後から右半側空間無視および右片麻痺は 消失 (失語のみ残存し NIHSS 1 点) した。術翌日の頭部 単純 MRI では, DWI で明らかな虚血像を認めず，頭部 MRA では左中大脳動脈の描出も良好であった，脳梗塞 の原因として塞栓性機序が疑われたため, 貧血の進行に
留意しながら heparin 持続静注 (10,000 単位/日)を開始す るとともに, 塞栓源検索を行った。頸動脈超音波検査で は両側頸動脈に異常を認めなかった. 経胸壁心エコーで は左室収縮能および左房径は正常範囲内であり, 弁膜の 異常も認めなかった. ホルター心電図では洞調律であ り，上室性期外収縮の多発も認めなかった。下肢静脈工 コーでは, 両下腿静脈の末梢分枝において深部静脈血栓 症を疑う陰影を認めたが，経頭蓋超音波によるマイクロ バブルテストは陰性であった。胸腹部造影 CT では，上 行大動脈から大動脈弓部にかけて明らかなプラークを認 めず, 左心耳内に血栓を示唆する所見を認めなかった. 以上から, 深部静脈血栓症を伴う塞栓源不明脳塞栓症 (embolic stroke of undetermined source: ESUS) と考え, Edoxaban $30 \mathrm{mg} /$ 日の内服へと移行した。 なお, 経食道 超音波および植込み型心電計については, 本人の同意が 得られなかったため施行できていない.

貧血の原因精査では，便ヒトへモグロビンは陰性，血 清鉄 $(204 \mu \mathrm{g} / \mathrm{dl})$ と血清フェリチン $(146.1 \mathrm{ng} / \mathrm{ml})$ に異常を 認めなかった。 血清 AFP, CEA, およびCA19-9 は正常 範囲内であり，胸腹部造影 CT でも悪性腫瘍を示唆する 
所見は認めなかった，上部消化管内視鏡検査では，胃全 体において慢性萎縮性胃炎の所見を認めた。関連する血 液検査項目としては, 血清 Helicobacter pylori IgG 抗体陰 性, 抗核抗体陰性, 血清補体価正常, リウマチ因子陰 性, 抗 DNA 抗体陰性, 抗カルジオリピン抗体 $\operatorname{IgG}$ 基準 值以下，ループスアンチコアグラント正常であったが, 血清 vitamin $B_{12}$ は $94 \mathrm{pg} / \mathrm{ml}$ と低值であった(抗胃壁細胞 抗体, 抗内因子抗体, 血清ホモシステインについては未 測定). 以上から, 悪性貧血の進行から高度大球性貧血 を来したものと判断し, 第3 病日より Mecobalamin 補充 療法 $(500 \mu \mathrm{g} /$ 日静注, 隔日)を開始した。以降, 時間経 過とともに神経症状は消失し，第 13 病日に自宅退院と なった(NIHSS 0 点, modified Rankin Scale: mRS 0). 退 院後は, 約 2 力月間当院外来にて Mecobalamin 補充療法 (500 $\mu \mathrm{g} /$ 日筋注, 隔日)を施行した. Hb が正常範囲内に 回復したことを確認の上, 内服による補充療法へと移行 し, その後もフォローアップを続けているが, 退院後 1 年の段階では脳梗塞再発㧍よび貧血進行のいずれも認め ておらず，経過は良好である。

本論文を投稿するにあたり，患者本人および家族から 同意を得た。

\section{考察}

本症例は, 悪性貧血を背景として脳梗塞を発症し, 脳 梗塞発症時に高度大球性貧血を伴っていたが, 輸血療法 および経皮的脳血栓回収術を迅速に行うことで良好な転 帰を得た。

通常, 食品とともに経口摂取された vitamin $\mathrm{B}_{12}$ は胃 酸および膵酵素により遊離し, 胃の壁細胞から分泌され る内因子と結合し, 複合体として回腸末端にある受容体 を介して吸収されるが, 悪性貧血では, 慢性萎縮性胃炎 に伴い, 胃壁細胞由来内因子の分泌が減少し, vitamin $\mathrm{B}_{12}$ 吸収障害を来す ${ }^{4)}$. 末梢血液学的検查では, 大球性 貧血, 白血球減少, 血小板減少を認め, 骨䯣では核の成 熟障害による巨赤芽球が見られることが特徵とされる。 胃壁細胞に対する自己抗体は, 悪性貧血患者に抢ける陽 性率が約 $90 \%$ と報告されており, 抗内因子抗体の特異 度も $90 \%$ と高いことから，これらの抗体は診断に有用 とされるが, 本邦においては保険適用外の検查項目と なっている, ${ }^{5,6)}$. 本症例では, 抗胃壁細胞抗体および抗 内因子抗体は測定していないが, 未梢血液学的検查所 見, 血清 vitamin $\mathrm{B}_{12}$ 低值, および慢性萎縮性胃炎を合 併していた点から, 悪性貧血の診断に矛盾はないと考え られる。

また, vitamin $\mathrm{B}_{12}$ はメチオニン代謝における補䤉素の
役割を担っており，ホモシステインからメチオニンへの メチル化の酵素反応に関わる. 従って, vitamin $\mathrm{B}_{12}$ 欠乏 は高ホモシステイン血症を惹起する。高ホモシステイン 血症は, 血栓塞栓症を含めた心血管危険因子として知ら れて抢り, vitamin $\mathrm{B}_{12}$ 欠乏は高ホモシステイン血症を介 して過凝固状態を生じさせる7). Vitamin $B_{12}$ 欠そによる 血栓塞栓症では, 樑部静脈血栓症や脳静脈洞血栓症など の静脈血栓症の報告が多い. 我々が渉猟し得た限りで は, vitamin $\mathrm{B}_{12}$ 欠乏による脳主幹動脈塞栓症を合併した 症例報告は, Zacharia らの 1 例のみであり ${ }^{8)}$, 本例は貴 重な症例と考えられる。本症例は, vitamin $\mathrm{B}_{12}$ 欠乏が関 連する全身の過凝固状態を背景とした ESUS と考えられ るが, D-dimer, FDP, 血清ホモシステインなどの評価 や, 経食道超音波, 植込久型心電計といった比較的侵襲 度の高い検查は未施行であるなど, 塞栓源検索において 十分ではない点もあった，今後の経過については，引き 続き外来でフォローアップする予定である.

貧血は, 脳卒中患者における転帰不良因子として知ら れている. Li らは, 13 のコホート研究を対象としたメ 夕解析の中で, 脳卒中患者に扔ける貧血の有病率は 17〜29\%であり，貧血を伴う脳卒中患者では死亡率が 39\%増加すると報告しており, 脳卒中患者においては貧 血を早期に是正することが転帰改善に重要であると説い ている22. 特に, 本邦における高齢者の脳梗塞では, $1.9 \%$ 症例で $\mathrm{Hb}$ 值が $10 \mathrm{~g} / \mathrm{dl}$ 未満であったと報告され ており, 突発完成型の塞栓症では, 覀性腫瘍や播種性血 管内凝固症候群などを背景とした非細菌性血检性心内膜 炎との関連が推察されている9 . また, 急速進行性貧血 と脳梗塞についても関連が示唆されており, 急性進行性 貧血の原因としては, 消化管出血が多く, 分水嶺領域の 多発性脳梗塞を認めることが特徴的である ${ }^{10,11)}$. 多量出 血と関連する脳梗塞では，血清鉄低下から骨䯣内巨核球 に抢ける血小板産生の脱抑制を来し，末梢血での血小板 増多および過凝固状態を惹起すると考えられている ${ }^{12}$. 本症例では, 脳梗塞発症前に急速進行性貧血を示唆する 病歴や身体所見を認めず，分水嶺領域の多発脳梗塞も認 めなかった．他に貧血の原因となり得る所見を認めな かったことから，悪性貧血による大球性貧血が無症候性 かつ慢性経過で $3.8 \mathrm{~g} / \mathrm{dl}$ まで進行し, 脳梗塞の発症に関 連したものと考えられた。

また, Akpinarらは, 機械的血栓回収療法を施行した 90 例を対象とした後方視的観察研究の中で, 脳梗塞発 症時に中等度以上の貧血 $(\mathrm{Hb}<10 \mathrm{~g} / \mathrm{dl})$ を有する群では, 3 力月後 $\mathrm{mRS}$ が有意に不良であったと報告している3 ${ }^{3)}$. 機械的血栓回収療法においては, 遠位塞栓を予防する目 
的で，デバイス回収時にバルーン付きガイディングカ テーテルから約 40〜 $50 \mathrm{ml}$ 程度の血液吸引を行う。その ため, 有効再開通を得るまでの pass 数が多いほど血液 吸引量も増加し, 貧血を助長する可能性がある。また, 解離性動脈瘤など体幹や下肢での出血性合併症が生じた 場合も，同様に貧血に対して悪影響を与え得る。本症例 では, 脳梗塞発症時に $\mathrm{Hb}$ の著明な低下 $(3.8 \mathrm{~g} / \mathrm{dl})$ を認め たにもかかわらず，幸いにして良好な転帰を得ることが できたが, 輸血による迅速な貧血是正と機械的血栓回収 療法を 1pass および最低限の血液吸引量で施行したこと が転帰改善の一助となったかもしれない。高度貧血を合 併した脳梗塞症例に押いて, 機械的血栓回収療法の適応 を判断する際には, 臨床状況と貧血を助長させるリスク を踏まえて判断することが望ましいと考えられる.

\section{結＼cjkstart語}

悪性貧血を背景として脳梗塞を発症し, 経皮的脳血栓 回収術により良好な転帰を得た 1 例について報告した。 近年, 脳梗塞急性期に打いて, 血管内再開通療法を急ぐ あまり，血液検査デー夕などの確認が疎かになっている 恐れがある，本稿で示したように，基本的な末梢血液項 目が脳梗塞患者の転帰に関わる可能性があることを念頭 に置いて，基礎疾患の確認と必要な全身管理の介入につ いて，脳梗塞急性期から対応を心掛けるべきである.

著者は日本脳卒中学会への COI 自己申告を完了して おり，本論文の発表に関して，開示すべき COI はない.

\section{参考文献}

1) Kiyohara $Y$, Ueda $K$, Hasuo $Y$, et al: Hematocrit as a risk factor of cerebral infarction: long-term prospective population survey in a Japanese rural community. Stroke 17: 687-692, 1986

2) Li Z, Zhou T, Li Y, et al: Anemia increases the mortality risk in patients with stroke: A meta-analysis of cohort studies. Sci Rep 6: 26636, 2016

3) Akpinar CK, Gurkas E, Aytac E: Moderate to severe anemia is associated with poor functional outcome in acute stroke patients treated with mechanical thrombectomy. Interv Neurol 7: 12-18, 2018

4）廣川 誠：悪性貧血. 日内会誌 103: 1609-1612, 2014

5) Lahner E, Annibale B: Pernicious anemia: new insights from a gastroenterological point of view. World J Gastroenterol 15: 5121-5128, 2009

6) Carmel R: Reassessment of the relative prevalences of antibodies to gastric parietal cell and to intrinsic factor in patients with pernicious anaemia: influence of patient age and race. Clin Exp Immunol 89: 74-77, 1992

7) Clarke R, Daly L, Robinson K, et al: Hyperhomocysteinemia: an independent risk factor for vascular disease. N Engl J Med 324: 1149-1155, 1991

8) Zacharia G, Shani D, Ortiz RA: Recurrent stroke in a patient with vitamin B12 deficiency and MTHFR mutation. Neurol Clin Pract 7: e1-e4, 2017

9）名倉博史，山之内博：老年者の貧血下における脳梗塞の 原因。日老医誌 29: 918-921, 1992

10) Tsai CF, Yip PK, Chen CC, et al: Cerebral infarction in acute anemia. J Neurol 257: 2044-2051, 2010

11）藤井悠里, 藤本 茂, 田川直樹ら：急速な貧血によって 生じた両側多発性脳梗塞の 1 例。脳卒中 38: 331-335, 2016

12) Naito H, Naka H, Kanaya $Y$, et al: Two cases of acute ischemic stroke associated with iron deficiency anemia due to bleeding from uterine fibroids in middle-aged women. Intern Med 53: 2533-2537, 2014 


\title{
Abstract \\ Pernicious anemia-induced ischemic stroke associated with good outcomes after mechanical thrombectomy: A case report
}

\author{
Sho Murase, M.D., Ph.D., ${ }^{1 * *}$ Yoshinori Maki, M.D.,, ${ }^{2, *}$ Masao Fukumura, M.D., ${ }^{2)}$ \\ ${ }^{1)}$ Department of Neurology, Kano General Hospital \\ ${ }^{2)}$ Department of Neurosurgery, Kano General Hospital \\ ${ }^{3)}$ Hikari Hospital
} Yuzo Kuroda, M.D., Ph.D., ${ }^{2)}$ Yasufumi Gon, M.D., Ph.D., ${ }^{1)}$ and Kazutomo Nakazawa, M.D. ${ }^{2)}$

\begin{abstract}
An 83-year-old man was admitted to our hospital with acute aphasia, left-sided conjugate eye deviation, and right hemiplegia. Brain computed tomography and diffusion-weighted magnetic resonance imaging were unremarkable; however, magnetic resonance angiography revealed proximal occlusion of the left middle cerebral artery (MCA). Blood test results showed severe macrocytic anemia with serum hemoglobin $3.8 \mathrm{~g} / \mathrm{dl}$ and mean corpuscular volume $144 \mathrm{fl}$. The patient was not administered intravenous recombinant tissue plasminogen activator because active gastrointestinal bleeding could not be immediately ruled out. He underwent mechanical thrombectomy together with blood transfusion, leading to complete recanalization of the left MCA. Upper gastrointestinal endoscopy revealed chronic atrophic gastritis. Blood test results showed a low serum vitamin $B_{12}$ level; therefore, the patient was diagnosed with severe macrocytic anemia secondary to pernicious anemia. He received anticoagulation and mecobalamin replacement therapy and was discharged on the 13th day without any sequelae. Clinicians should carefully evaluate underlying diseases, including anemia, before determining the indications for endovascular treatment in patients with acute ischemic stroke.
\end{abstract}

Key words: pernicious anemia, severe anemia, mechanical thrombectomy, vitamin $\mathrm{B}_{12}$ deficiency

(Jpn J Stroke 43: 447-451, 2021) 